1994-01-01

\title{
Using Statistics in Industry - Quality Improvement Through Total Process Control
}

\author{
Edward Sweeney \\ Technological University Dublin, edward.sweeney@tudublin.ie \\ Gordon Betteley \\ Neville Mettrick
}

See next page for additional authors

Follow this and additional works at: https://arrow.tudublin.ie/nitlbk

Part of the Business Administration, Management, and Operations Commons, and the Engineering Commons

\section{Recommended Citation}

Sweeney, E., Betteley, G., Mettrick, N., Wilson, D.: Using Statistics in Industry - Quality Improvement Through Total Process Control. Published: in Prentice Hall (Manufacturing Practitioner Series), 1994. Second edition published by Pearson Educational in 1997 under the title The Theory and Practice of Statistical and Allied Techniques in the Improvement of Processes in Manufacturing and Commercial Organisations.

This Book is brought to you for free and open access by the National Institute for Transport and Logistics at ARROW@TU Dublin. It has been accepted for inclusion in Books/Book chapters by an authorized administrator of ARROW@TU Dublin. For more information, please contact arrow.admin@tudublin.ie, aisling.coyne@tudublin.ie,gerard.connolly@tudublin.ie.

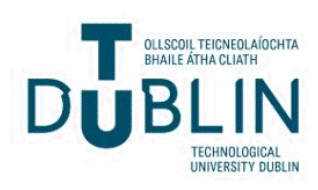




\section{Authors}

Edward Sweeney, Gordon Betteley, Neville Mettrick, and David Wilson 


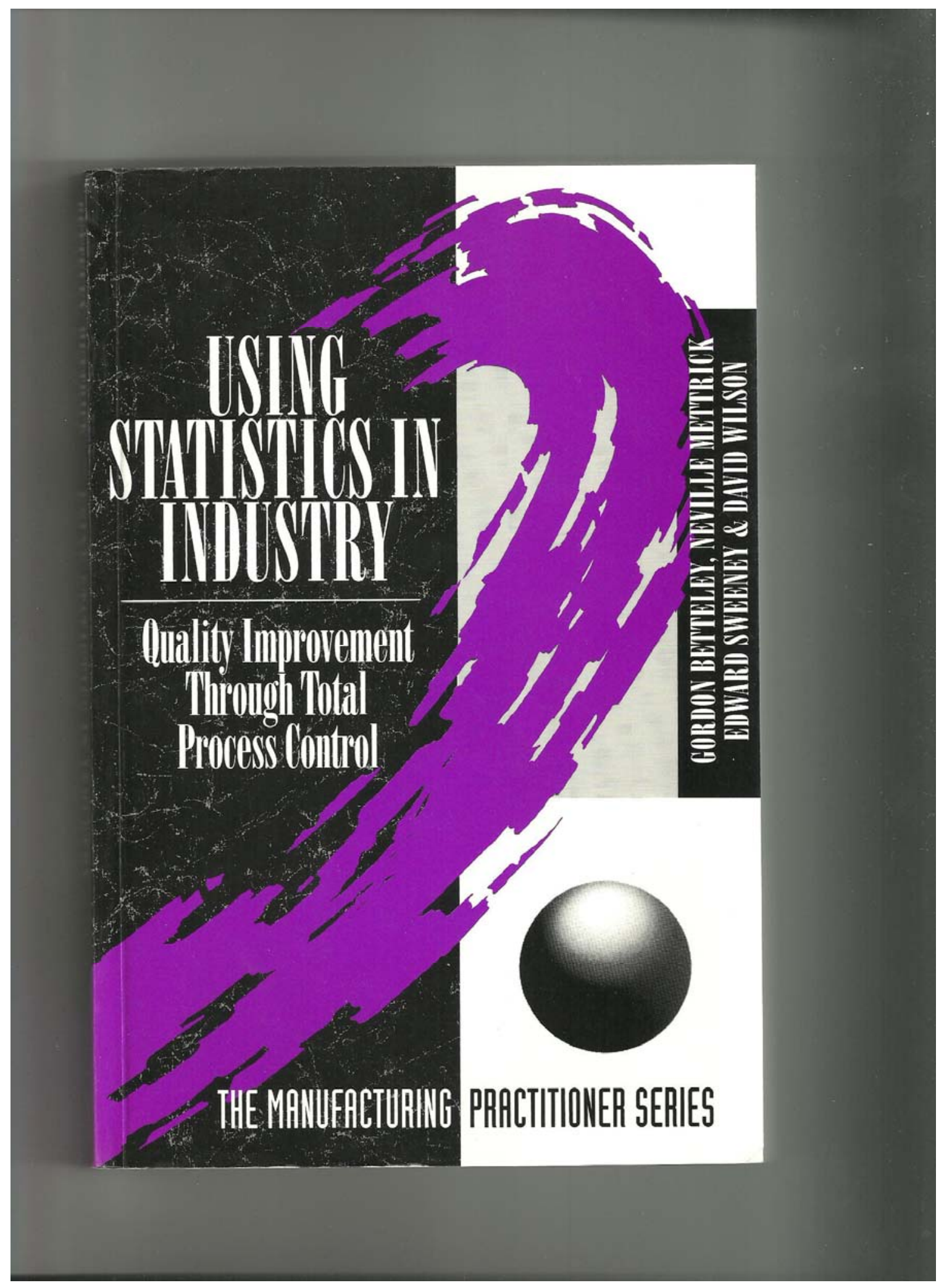




\section{THE MANUFACTURHGG PARCTITIONEE SEAIES}

\section{ISING STATISTIIS IN INDISTRY \\ Quality Improvement Through Total Process Control}

Gordon Betteley, Neville Mettrick, Edward Sweeney \& David Wilson

For many years the need to bridge the gap between theoretical and practical technology has been recognised, but it is only recently that universities and industrial companies have collaborated successfully to relate learning to the ongoing practical needs of industry.

Using Statistics in Industry is an ideal workplace reference for anyone who needs to improve their understanding of the use of statistics in process control. Using practical examples the authors explain and illustrate all the basic statistical techniques and, since much of the material is derived from courses jointly developed by Warwick University and household name industrial firms such as Rover Group, Rolls-Royce, British Airways and Lucas, the authors have ensured that content and coverage is proven to be relevant and presented in an easily accessible style.

\section{Contents include}

- Data presentation - Probability and probability distributions Estimation

- Significance testing $\bullet$ Process control Control charts

Using Statistics in Industry provides an invaluable resource for production and technical support staff working in quality management, and section leaders and cell managers responsible for ensuring that processes are under control. It may be read as a whole or used as a reference as the need arises. No previous knowledge of statistics is assumed or required but references to further reading are included in every chapter.

Equally it can be used on first and second year Industrial Statistics and Quality Control courses and first year Applied Statistics courses.

Gordon Betteley is in the department of Statistics and Operational Research at Coventry University, and has written numerous papers, books and industrial reports; Neville Mettrick is Statistical Process Control Manager in the Rover Group, has been involved with development of Total Quality Management in the motor vehicle industry since the mid $1960 \mathrm{~s}$, and is an advisor and visiting lecturer at several UK universities; Edward Sweeney is a member of the Warwick and visiting lecturer at several UK universities; Edward Sweeney is a member of the Warwick
Manufacturing Group at the University of Warwick and works in collaboration with the leading UK and international engineering companies. David Wilson, after several years as an engineer in manufacturing industry, is now head of the Applied Statistics Group at Aston Business School. 